\section{Ben Fickling}

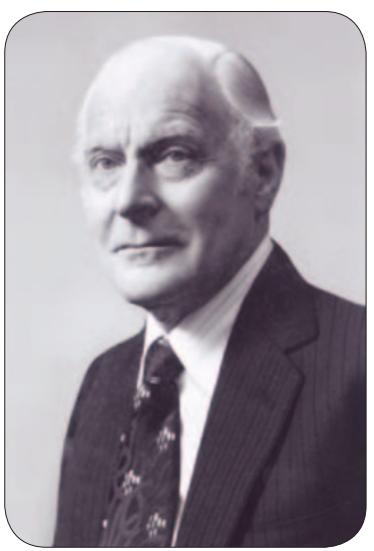

Ben Fickling died in his 98th year on 27 January 2007. He was born the year Henry Ford launched the model $\mathrm{T}$ and Louis Bleriot crossed the English Channel by monoplane. Ben was a link with a different world and a highly respected leader and pioneer throughout a long life.

He was born on 14 July 1909 at 49 Sloane Street. This was his parents' home and also the location of the very long established dental practice, which his father had joined after qualification in 1901.

Educated at Lucton School and Framlingham College, at 18 he began to study medicine and dentistry concurrently at the Royal Dental Hospital and St. George's Hospital.

He qualified LDS RCS in 1932 and MRCS LRCP in 1934 and in 1938 passed the final FRCS. After serving as a house surgeon at the Royal, Ben was appointed assistant dental surgeon to the Royal Dental and also to St George's Hospital.

On the advice of Wilfred (later Sir Wilfred) Fish he spent time in Vienna and had the great privilege of studying under Gottlieb, Orban, Hans Pichler, Bohler and Finsterer, all names evocative of a great period in Viennese medicine.

At the outbreak of the Second World War he was drafted into the Emergency Medical Service at St George's, serving there throughout the Blitz. Literature on the management of facial injuries was scarce. In collaboration with Warwick James, who had had considerable First World War experience, he wrote as a matter of urgency Injuries of the Jaws and Face which was published in 1940.

They also translated and published abstracts from Réné Le Fort's 1901 account of his macabre experiments, which resulted in the now universally accepted classification of facial fractures. At this time he was also appointed to the Plastic and Maxillofacial Unit led by Rainsford Mowlem at Hill End Hospital, which subsequently moved in 1953 to Mount Vernon Hospital, Northwood.

His disciplined, honest, courteous and meticulous approach, coupled with his sense of loyalty and duty, influenced many trainees, among whom were Gordon Fordyce, Paddy Killey and Norman Rowe. The Faculty of Dental Surgery of The Royal College of Surgeons of England was founded in 1947 and Ben was awarded the FDS that same year. Ten years later he was elected to the Board and served as Dean from 1968 to 1971.

He played a pivotal role in the development of maxillofacial surgery in this country; in 1962 he was an original member of the

\section{Ben was a link with a different world and a highly respected leader and pioneer throughout a long life.}

Council of the British Association of Oral Surgeons and President in 1967. He was also a founder member of the International Association of Oral Surgeons, subsequently serving on its Council.

At the introduction of the National Health Service, Ben decided against a full-time appointment in oral surgery but retained his outpatient and operating sessions at the Royal, St George's and Mount Vernon. He loved the continuing contacts of a family practice, in which he worked part-time for a total of 48 years before retiring in 1980.

He was a director of the Medical Sickness Annuity and Life Insurance Society (now Wesleyan Medical Sickness) from 1967 to 1986, adding yet another dimension to a busy life.

He lectured extensively around the world, including a tour to South America sponsored by the British Council. He gave the Charles Tomes Lecture in 1956, the first Everett Magnus Oration in Melbourne in 1971 and the Webb Johnson Lecture in 1976.

Ben was in demand as an examiner at all levels of dental surgery for 27 years and when it was agreed in the mid 1970s to establish a postgraduate examination in general dental surgery, he was chosen as the natural person to plan and see this through to fruition. As chairman of examiners, he presided over the first MGDS examination in 1979.

He was a keen sportsman, who enjoyed tennis and cricket. He also played hockey for Hampstead and the Tramps touring side and was capped for Middlesex. Having skied before the war in Adelboden, he continued skiing into his seventies and passed the passion on to his daughter, two sons and seven grandchildren.

In retirement he took up golf and spent more time in his beautiful garden and continued travelling.

He faced the challenge of great age with patient, uncomplaining dignity and retained his intellect to the end.

Ben had a very happy family life and was ably supported in all he did by the wondrous Shirley, to whom he was married for 63 years.

Among many honours, the CBE in 1973 and the award of the FFGDP at the age of 92 stand out.

Blessed with an enquiring mind and a good eye for a ball, he was a faithful Christian, who enjoyed his life and talents. The development of oral surgery and the high standards in general practice both owe a great deal to him.

P. A. B. and C. A. F 